\title{
Kolaborasi Masyarakat dan Akademisi dalam Produksi Pengetahuan Arkeologi di Masjid Sang Cipta Ras, Cirebon, Jawa Barat
}

\author{
Adieyatna Fajri \\ Departemen Arkeologi, Fakultas Ilmu Budaya, Universitas Gadjah Mada \\ Posel: adieyatna.fajri@ugm.ac.id
}

\begin{abstract}
The Sang Cipta Rasa Great Mosque has become one of cultural assets and the icon of the people and Cirebon city. Unfortunately, currently information about the significance of the Cipta Cipta Mosque in terms of art and architecture is still very limited. Through a people-centered cultural heritage preservation approach and the ideas brought by community archaeology, this service activity aims to produce and circulate knowledge collaboratively between the community and academics about the significance of the Sang Cipta Rasa Mosque. The cultural identity of the cosmopolitan and multicultural community of Cirebon was appointed as the main theme of this community service product in the form of informative leaflets.
\end{abstract}

Keywords: Sang Cipta Rasa Mosque, people-centered, community archaeology, multicultural

\begin{abstract}
Abstrak
Keberadaan Masjid Agung Sang Cipta Rasa telah menjadi salah satu aset kebudayaan masyarakat dan ikon kota Cirebon. Sayangnya, saat ini informasi mengenai signifikansi Masjid Sang Cipta Rasa dari sisi gaya seni maupun arsitektur masih sangat terbatas. Melalui pendekatan pelestarian cagar budaya people-centred dan gagasan yang dibawa community archaeology, kegiatan pengabdian ini bertujuan untuk memproduksi dan mensirkulasikan pengetahuan yang diproduksi secara kolaboratif antara masyarakat dan akademisi tentang signifikansi Masjid Sang Cipta Rasa. Identitas kultural masyarakat Cirebon yang kosmopolitan dan multikultur diangkat menjadi tema utama produk pengabdian berupa leaflet yang informatif.
\end{abstract}

Kata kunci: Masjid Sang Cipta Rasa, people-centred, community archaeology, multicultural

\section{Pengantar}

Kegiatan pengabdian masyarakat ini bertolak dari pengalaman pribadi penulis yang mengunjungi Masjid Agung Sang Cipta Rasa pada akhir bulan Desember tahun 2017. Dalam kunjungan tersebut, penulis mengajak berbincang beberapa pengurus takmir terkait dengan signifikansi keberadaan Masjid Agung Sang Cipta Rasa bagi masyarakat di Kota Cirebon. Sayangnya, para pengurus takmir masjid yang telah lama berpartisipasi aktif dalam menjaga kelestarian bangunan cagar budaya tersebut kurang memahami nilai penting yang dimiliki oleh Masjid Sang Cipta Rasa. Hal yang serupa juga terjadi pada para pengunjung masjid, terutama yang berasal dari luar daerah. Meskipun mereka mengakui nilai sejarah dan estetika yang ada pada Masjid Sang Cipta Rasa, informasi yang mereka dapatkan bersifat sangat parsial. Sebagian masyarakat, bahkan mereka 
yang tinggal di sekitar lingkungan masjid, hanya sebatas mengetahui bahwa masjid tersebut merapakan salah satu peninggalan dari Sunan Gunung Jati, seorang figur yang dikaitkan dengan berdirinya Kesultanan Cirebon.

Ditinjau dari sisi sejarah ataupun arsitektur, Masjid Sang Cipta Rasa tidak diragukan lagi merupakan salah satu contoh karya arsitektur masjid bergaya vernakular Asia Tenggara yang sangat unik. Elemen gaya seni atupun arsitektur bangunan masjid ini telah melahirkan berbagai macam karya tulis ilmiah. Meskipun memiliki kontribusi besar bagi diskusi ilmiah di bidang arkeologi dan arsitektur, pada kenyataannya justru melahirkan satu kesenjangan yang besar di masyarakat. Kesenjangan informasi yang dimiliki kalangan peneliti dengan masyarakat umum acap kali terjadi ketika seorang peneliti berhenti memasyarakatkan produk penelitiannya sehingga hanya terbatas menjadi konsumsi di lingkaran para cerdik cendekia.

Kegiatan pengabdian ini bertujuan untuk membawa hasil-hasil penelitian yang masih berputar dalam sirkulasi jaringan para peneliti, terutama ahli arkeologi, sejarah, atupun arsitektur ke arena yang dapat diakses secara langsung oleh masyarakat. Dimensi kegiatan pengabdian masyarakat ini mengarah langsung pada masyarakat luas dalam bentuk penyajian pengetahuan yang informatif serta mudah dipahami. Kegiatan ini didesain secara berkelanjutan dengan memperhatikan aspek-aspek yang dibutuhkan masyarakat, baik pengelola masjid maupun masyarakat luas. Kegiatan penyusunan media diseminasi pengetahuan dalam bentuk yang informatif ini sejatinya merupakan awal dari sebuah kegiatan besar dalam bingkai membentuk kesadaran dan partisipasi aktif masyarakat untuk menjaga kelestarian tinggalan kebudayaan dari masa lalu.

\section{Desain Program dan Metode}

Program pengabdian ini mengadopsi metode pendekatan people-centred approach yang telah dipopulerkan oleh ICCROM (International Centre for the Study of the Préservation and Restoration of Cultural Property) pada tahun 2015. Pendekatan ini bukanlah hal baru dalam diskusi pelestarian cagar budaya. Dalam dunia arkeologi, telah lebih dulu dikenal istilah 'community archaelogy' yang telah berkembang sejak medio tahun 1970 yang lebih mengedepankan partisipasi aktif masyarakat dalam membentuk pengetahuan tentang khazanah ilmu arkeologi (Liddle, 1985). Seiring dengan meningkatnya kesadaran bahwa produksi pengetahuan tentang sebuah tinggalan budaya dari masa lalu tidak mutlak menjadi domain para arkeolog, paradigma mengenai pelestarian cagar budaya juga perlahan mengalami perubahan.

Pendekatan people-centred selama ini berusaha untuk melibatkan masyarakat sebagai inisiator dalam proses perlindungan ataupun pemanfaat cagar budaya, khususnya yang bersifat living monument. Pendekatan ini harus memperhatikan kebutuhan dasar masyarakat lokal dan potensi kesempatan yang ada sehingga membawa kebermanfaatan yang berkelanjutan (ICCROM, 2015). Pendekatan living monument menjadi fokus utama mengingat adanya hubungan erat antara masyarakat dan monumen tersebut yang dengan sendirinya menciptakan ruang bagi adanya perubahan ataupun evolusi. Antisipasi terhadap perubahan-perubahan seiring dengan pemenuhan kebutuhan masyarakat terhadap pemanfaatan cagar budaya harus direkonsiliasikan dengan prinsip dasar pelestarian agar tercipta gerakan yang harmonis antara dua kepentingan tersebut. 
Persoalan utama yang dijumpai di Masjid Agung Sang Cipta Rasa berdasarkan hasil wawancara dengan takmir masjid ataupun pengunjung adalah tidak adanya informasi yang memadai tentang masjid tersebut. Dalam rangka mengatasi persoalan ini, melalui pendekatan people-centred maka kegiatan pengabdian ini berusaha menjawab persoalan tersebut dengan cara meningkatkan keterlibatan masyarakat dalam memproduksi pengetahuan tentang masjid. Produksi pengetahuan yang dimaksud dalam kegiatan ini adalah dengan menggali informasi dengan penekanan pada aspek-aspek yang dapat memperkuat identitas kultural masyarakat Cirebon.

Melalui pendekatan people-centred yang dikombinasikan dengan ide yang dibawa oleh community archaelogy, program pengabdian ini berjalan sesuai alur diagram berikut.

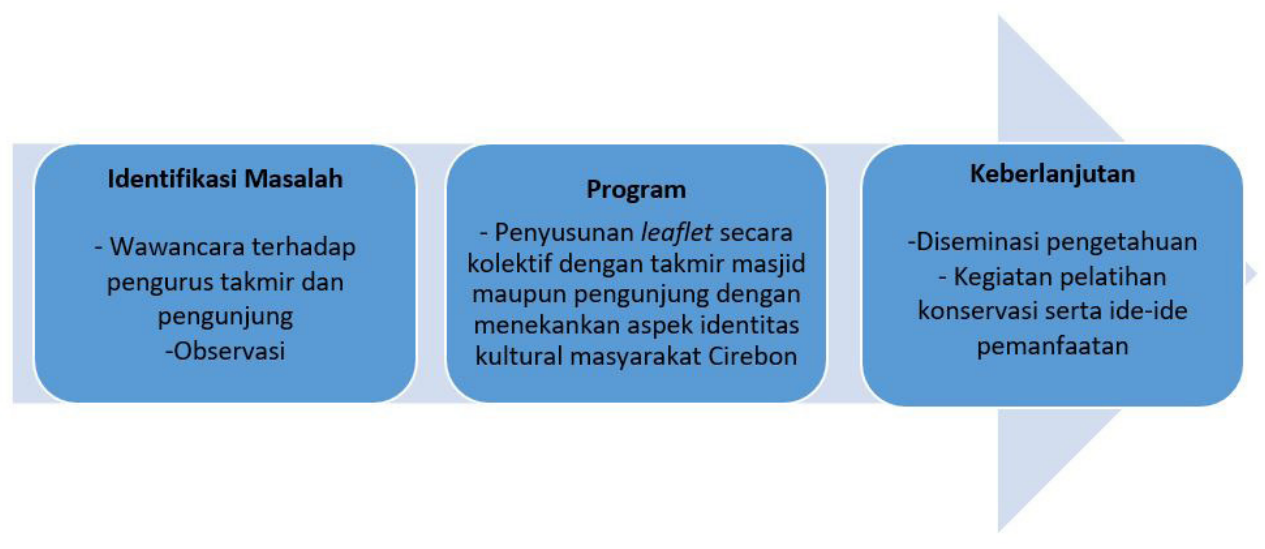

\section{Tahap Pelaksanaan}

Pengabdian masyarakat ini dimulai dengan kegiatan identifikasi masalah yang ditempuh dengan metode wawancara dan observasi. Sebagaimana tujuan dasar dari pendekatan peoplecentred yang menekankan pada aspek kebutuhan masyarakat, maka identifikasi masalah ini diarahkan untuk mengungkapkan masalahmasalah yang secara real terjadi. Berdasarkan hasil wawancara dengan pengurus takmir, saudara Ismail (5 Mei 2018), persoalan utama yang

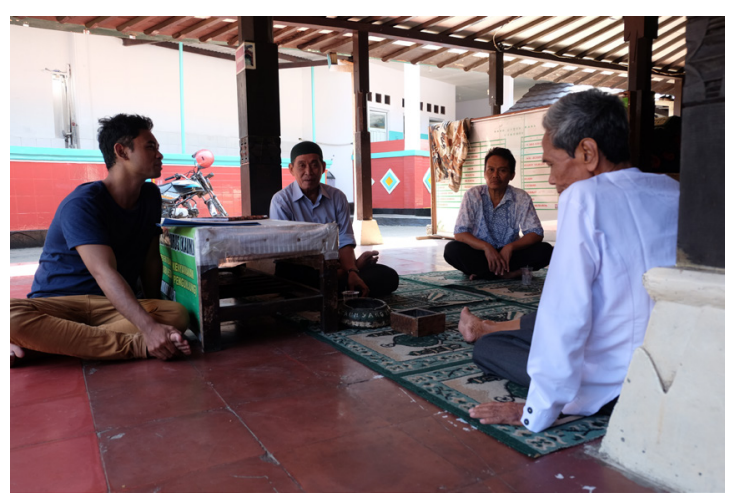

Ilustrasi 1. Diskusi dengan pengurus takmir Masjid Agung Sang Cipta Rasa. Dokumentasi: Anglir Bawono. dihadapi saat ini adalah pengetahuan masyarakat yang bersifat parsial terhadap signifikansi Masjid Agung Sang Cipta Rasa dan masalah terkait dengan kerusakan-kerusakan fisik bangunan. Dua masalah ini menjadi sasaran utama kegiatan pengabdian masyarakat ini. Akan tetapi, mengingat adanya keterbatasan waktu maka masalah tersebut akan dikaji satu per satu. Pada tahap pertama ini, kebutuhan terhadap adanya informasi tentang masjid akan menjadi fokus kegiatan. Sementara itu, masalah terkait dengan kerusakan fisik bangunan akan menjadi fokus kegiatan pada tahap selanjutnya. 
Proses selanjutanya adalah penyusunan program yang dilakukan secara kolektif melalui kegiatan penulisan leaflet yang mencerminkan identitas kultural masyarakat Cirebon. Leaflet dianggap sebagai media yang cukup informatif dan praktis sehingga dapat membekali masyarakat dengan informasi yang memadai. Mengingat banyaknya elemen gaya seni ataupun arsitektur pada Masjid Agung Sang Cipta Rasa maka proses seleksi dilakukan terhadap materi-materi yang ingin disampaikan di dalam leaflet. Setelah dilakukan diskusi secara mendalam dengan takmir masjid dan warga masyarakat Cirebon, akhirnya dapat disepakati bahwa tema utama materi leaflet tersebut adalah multikulturalitas atau keberagaman. Selain dari sisi tinggalan budaya materi, aspek ini juga didukung oleh latar belakang masyarakat Cirebon yang terdiri atas beberapa kelompok etnis masyarakat yaituJawa, Sunda, Arab, dan Cina.

Penyusunan materi leaflet dilakukan dengan melakukan kegiatan pendokumentasian terhadap elemen dan fitur yang terdapat di Masjid Agung Sang Cipta Rasa yang mencerminkan nilai estetika serta khazanah arsitektur yang tinggi. Pendokumentasian dilakukan dengan cara melibatkan masyarakat setempat sehingga terjadi diskusi tentang signifikansi Masjid Agung Sang Cipta Rasa dari sisi akademik dan sosial. Ornamentasi khas Cina berupa Chinese knott atau dalam bahasa lokal disebut seni slimpetan, misalnya, dengan mudah ditemui di beberapa bagian masjid (lihat Ilustrasi 2). Dari sisi gaya seni, aspek yang sangat menonjol di dalam masjid adalah adanya percampuran unsur-unsur seni dari berbagai kebudayaan Jawa, Cina, dan Arab. Selain ketiga unsur tersebut, unsur kebudayaan pra-Islam juga masili sangat kental mempengaaihi ornamentasi pada beberapa bagian masjid, khususnya pada bagian mihrab (lihat Ilustrasi 3).

Kegiatan pengabdian ini bersifat berkelanjutan. Diseminasi ilmu pengetahuan akan diikuti oleh program-program nyata lainnya yang terkait dengan upaya pelestarian fisik bangunan. Selain produksi pengetahuan yang telah dilakukan secara kolektif

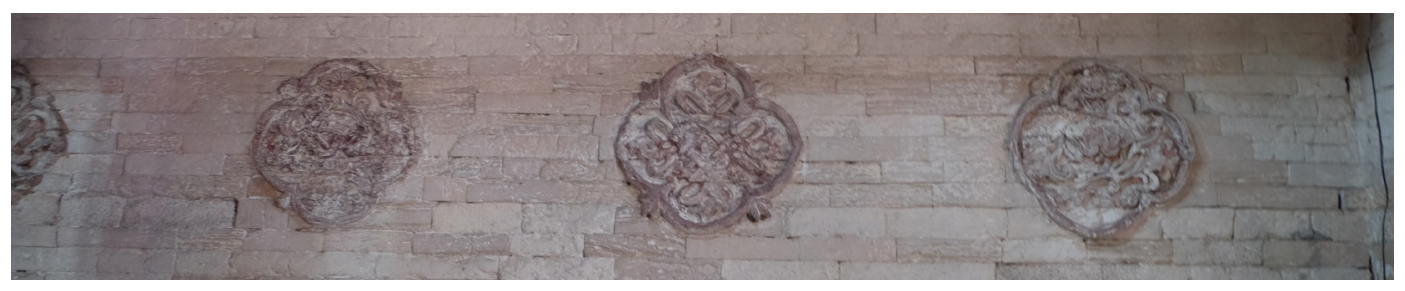

Ilustrasi 2. Omamentasi bercorak Cina pada dinding ruang utama masjid. Dokumentasi: Anglir Bawono.

Ilustrasi 3. Mihrab dengan gaya seni praIslam. Dokumentasi: Anglir Bawono.

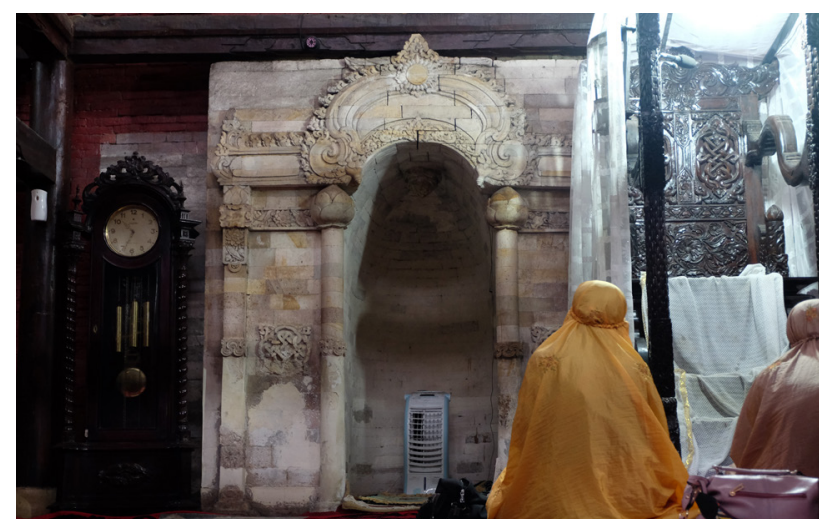


dengan cara melibatkan masyarakat dalam aspek seleksi materi, tema, ataupun narasi, program lain yang dapat digagas antara lain adalah melakukan tukar menukar informasi antara praktisi/akademisi dengan masyarakat lokal setempat mengenai upaya konservasi bangunan berbahan dasar kayu dan bata merah.

\section{Program Berkelanjutan}

Sebagaimana telah dijelaskan di atas, kegiatan pengabdian masyarakat ini direncanakan dalam beberapa tahap. Tahap pertama yaitu diseminasi ilmu pengetahuan yang dibentuk secara kolektif bersama masyarakat akan diikuti oleh kegiatan-kegiatan lain. Selain kegiatan konservasi dan perumusan gagasan menyangkut pemanfaatan masjid, program lain yang akan diwujudkan yaitu penyusunan buku tentang Masjid Agung Cipta Rasa. Respons positif terhadap dibuatnya leaflet yang menyediakan informasi secara praktis mendorong masyarakat untuk memproduksi pengetahuan dalam bentuk yang lebih komprehensif. Takmir Masjid Agung Sang Cipta Rasa mengundang UGM untuk menyusun buku yang memuat kajian mendalam terhadap masjid tersebut. Takmir masjid beserta masyarakat yang selama ini memahami nilai filosofi yang ada di dalam masjid pada program selanjutnya akan berkolaborasi dengan penulis untuk menyusun buku tersebut. Konten di dalam buku tersebut merupakan hasil dari proses diskusi antara masyarakat dan akademisi yang akan mengupas aspek nilai-nilai baik filosofis, seni, maupun teknis. Dengan demikian, keterlibatan masyarakat dalam menulis sejarah dan budayanya sendiri diharapkan mampu meningkatkan apresiasi masyarakat terhadap aset kebudayaan yang mereka miliki.

\section{Penutup}

Kegiatan pengabdian masyarakat ini adalah sebuah usaha kecil untuk menginisiasi terbentuknya sinergitas dan kolaborasi antara akademisi dan masyarakat dalam memproduksi ilmu pengetahuan, khususnya dalam bidang arkeologi. Melalui pendekatan people-centred, kegiatan ini telah menghasilkan satu bentuk pengetahuan yang meskipun sederhana, tetapi mencerminkan keterlibatan masyarakat dalam menafsirkan data arkeologi. Kegiatan ini didesain untuk dilaksanakan secara berkelanjutan. Pada tahap selanjutnya, kolaborasi antara akademisi dan masyarakat akan diperluas dengan program penulisan buku tentang Masjid Sang Cipta Rasa. Masyarakat akan terlibat dari proses perumusan topik, observasi, dan pembentukan gagasan.

\section{Daftar Pustaka}

Alamsyah, Suwardi. (2010). Nilai Budaya Arsitektur Masjid Sang Cipta Rasa Cirebon Jawa Barat. Patanjala. Vol. 2, no. 2. Hlm. 172-190.

Marshall, Yvonne. (2002). What Is Community Archaeology?. World Archaeology. Vol. 34, no. 2. Hlm. 211-219.

Moshenska, Gabriela, dan Sarah Dhanjal. (2011). Introduction: thinking about, talking about, and doing community archaeology. Community Archaeology Thèmes Methods and Practices. Oxford: Oxbow Books. 